\title{
FAMILY RESILIENCE IN THE FAMILY OF A TERRORIST
}

\author{
Zarina Akbar, Indah Fujiati \\ Faculty of Psychology, Universitas Negeri Jakarta \\ Jalan Rawamangun Muka, Jakarta Timur, Jakarta 13220, Indonesia \\ zarina_akbar@unj.ac.id
}

\begin{abstract}
Acts of terrorism carried out by terrorists have an impact on the families of the terrorists, especially if their families remain stay in their environment. The families of the terrorists experience many changes following the terrorism committed by their family member(s) and even putting the families in a crisis. This research aims to obtain a description of family resilience in the families of terrorists following a terrorism. This research uses a qualitative approach with a case study method. The data collection techniques used were direct observation and interview with the family (both parents of the terrorist/perpetrators). Data triangulation was done with the significant others (cousins of the terrorist/perpetrator and local public figures). The research subjects were a particular family consisting of a father, a mother, and a child (the child was the perpetrator of a terrorism). The results showed that the resilience aspects of the belief system in the family of the terrorist can interpret all events well, organizational patterns that can adapt to situations but with a less open communication to one another. The family of the terrorist have gone through the process of becoming resilient and have used the strength and resources available to the family to increase resilience in the family, especially with respect to the social stigma of society given to the family following the terrorism.
\end{abstract}

Keywords: family resilience; family; terrorist

\section{INTRODUCTION}

Terrorism is behavior that is conducted by means of violence and has a target goal (which has no close relationship or family relationship with the perpetrator) that can result in damage, death, fear and mass despair or policy (Mustofa, 2012). Acts of terrorism harm all elements of society and have longterm social, economic, and psychological effects on victims and their families (Waheed \& Ahmad, 2012). In the last three years there have been seven incidents that have attracted considerable attention, Thamrin Bomb, Mapolresta Solo Bomb in Central Java, Molotov Cocktail in East Kalimantan and West Kalimantan, Kampung Melayu Bus Terminal Bomb, Mako Brimob Tragedy, Surabaya Church Bomb and Sidoarjo Bomb (Badriyanto, 2018).

The family of terrorists is a family based on blood relations with one or more members of the family having committed acts of terror in Indonesia, especially in murder cases, along with the use of weapons for a specific purpose
(Nurfitri, 2018). The families of terror perpetrators will face intimidation, negative perceptions, and discrimination resulting in feelings of depression and exclusion from the community (Sujoko \& Mukti, 2018). When terrorists are arrested, their families become suspected terrorists thus this has a significant impact on the families (Magfur \& Muniroh, 2013). The impact of the arrests affects the children who become shocked and embarrassed as well as the emotional trauma, the wives must become the head of the family (Rahmawati et al., 2018). The heavy psychological burden which will continue to overshadow them throughout life is the stigma of being from a terrorist family (Ahmad \& Ula, 2012). Being labelled as belonging to a terrorist family is certainly not an easy thing (Ulfiyatun, 2015). The psychological pressure receive from the surrounding environment makes them feel helpless, sad and unwanted (Jayanti \& Indrawati, 2013). They get treated differently by other families and this limits their social scope, leaving them feeling isolated (Asiyah et al., 2014; Guru, 2012) and excommunicated (Guru, 2012) 
The families feel upset, traumatized, and full of regret and would not want this incident to happen again (Rufaedah \& Putra, 2018). They may deserve a negative label and social punishment by limiting their wiggle room in social life. People will tend to identify people who approach them as their accomplices, thus seemingly letting them and their families live isolated from their social environment (Nurfitri, 2018). In the research conducted by Rufaedah and Putra (2018) two wives of terrorists decided to move, aiming to avoid stigma from the community, the family felt upset, traumatized, and regret and would not want this kind of incident to happen again. The act perpetrated by member of the family can have a significant impact on the family as a whole, they may also experience a lot of changes after the events which result in a crisis situation. According to Walsh (2003, in Qiu et al., 2021) family resilience is the ability of a family, as a functional system, to survive, and recover from such difficulties. How a family deals and manages such challenges and moves forward with life will have immediate and long-term effects for each family member and for the survival of the family as a whole (Walsh, 2016). Walsh (2003, in Qiu et al., 2021) say that family resilience is built through three components: family belief system, organizational pattern, and family communication or problem-solving process. There are several factors that influence the formation of family resilience, they are duration, stage of family development, internal and external support, and cultural and economic diversity.

Based on the description above, a conclusion can be made that the consequences of acts of terrorism are not only endured by the perpetrators, but also their families when they remain living in the same neighborhood. According to this research, the families of terrorists experience significant changes after the incidents. Research on family resilience within the family of a terrorist in Indonesia is still very limited. This research then is unique, in attempting to illustrate the resilience within terrorist families.

\section{METHOD}

The criteria of the subjects in this research were families with one or more members who committed acts of terror in Indonesia, especially involving murder cases along with the use of weapons for a specific purpose. This research involved a family consisting of father, mother, and three children, but the subjects of this research were the father (AB) and mother (MI), while SL (second child) refused to be interviewed and $\mathrm{SH}$ (third child) lived elsewhere. The terrorist was their first child and was killed during the incident. His family lived in a village in the city of $\mathrm{S}$, and their son was involved in the Sarinah Bombing (2016). The interview was conducted in July 2019, about 3 years after the terror acts.

This research used a qualitative approach with a case study method. According to Poerwandari (2013) case studies are applied to find out in depth, about phenomena that occur in real life using various existing data sources. The qualitative approach allows researchers to explore and gain a deeper understanding of the illustration of family resilience within terrorist families. Data collection methods were conducted by observation and interview. The interview was managed in a semistructured manner, it had guidelines during the process but adapted to the conditions at that time (Rahmah \& Widuri, 2011). Interviews were run many times with the aim of gaining a deep understanding of the subjects.

Researchers compiled interview guidelines, observation sheets, and inform consent before the interviews. Interview guidelines were based on Walsh's family resilience dimension (2006, Ilias et al., 2019) consisting of three dimensions each having three subdimensions. These sub-dimensions are divided into several indicators, and some of them were elaborated into questions which were asked during the interview. After the preparation process was completed, the next process was expert judgement with two 
lecturers of Clinical Psychology of Universitas Negeri Jakarta who were also psychologists on interview guides, observation sheets and inform consent. After receiving input, the researchers revised and repeated expert judgement process until they obtained the final interview guidelines, observation sheets, and informed consent for data collection.

The researchers scheduled the interview before it was conducted, and the subjects were free to decide the time and location for the interview so it would not disturb their activities, it was decided that the interview location would be at the subjects' home in the city of S. At the first meeting before the interview process began, the researchers explained the purpose of the interview and asked the subjects for permission as to whether they would be willing to participate in this research, as well as the use of a voice recording device during the interview. The researchers explained the questions that would be asked were from a psychological aspect and the researchers were not from any government institution. The subjects asked researchers not to publish their names, take pictures of their faces, or publish the full address of their home. The researchers then gave informed consent as a sign that the family allowed researchers to perform the research procedure. However, when the researchers asked SL (SN sibling) permission for an interview, SL refused and insisted on not wanting to be interviewed if it was about terrorism or the sibling. Researchers did not manage to interview SL, therefore interviews were only conducted on the father $(\mathrm{AB})$ and mother (MI) of the terrorist.

Table 1.

General Information of The Subjects

\begin{tabular}{ccccc}
\hline Subjects & Status & Age & Occupation & Interview Duration \\
\hline AB & Terrorist's Father & 65 years & Goat Farmer & $\begin{array}{c}3 \text { times, each about 1-1.5 } \\
\text { hours }\end{array}$ \\
MI & Terrorist's Mother & 58 years & Selling Cilung & $\begin{array}{c}3 \text { times, each about 1-1.5 } \\
\text { hours }\end{array}$ \\
HM & Terrorist's Cousin & 60 years & $\begin{array}{c}\text { Retired Civil } \\
\text { Servant }\end{array}$ & 1 time, about 1-1.5 hours \\
TA & Public Figure & 47 years & Public Figure & 1 time, about 1-1.5 hours \\
\hline
\end{tabular}

Researchers used interview guidelines and voice recording devices to simplify the process of data retrieval and data analysis. The same procedures applied when interviewing significant others. With these tools, researchers composed verbatim interviews, the results of the verbatim was then given coding and analyzed by categorizing the answers from the subjects into the dimension of family resilience, so the illustration can be seen. Observations were performed in each interview process by writing down the general impression (the atmosphere, space and place of the interview, the physical state and appearance of the subjects) and the emotional state of the subjects (expression, body language and the way they answered questions).

In this research, data triangulation was managed by interviewing significant others, the terrorist' cousin, nephew of $\mathrm{AB}$ and $\mathrm{MI}$ (HM) and a public figure (TA) in the neighborhood where the family of the terrorist live. HM was a 60-year-old retired civil servant principal. The interview was conducted in HM's house where he raises chickens on his small farm and during the 
interview, he was informative and friendly. Interview with TA was conducted in his office at the Village Hall. TA provided a lot of information about the subjects and behavior of the community towards the subjects. Shortly after the Sarinah Bombing, HM and TA were at the perpetrator's house.

\section{RESULT AND DISCUSSION}

\section{Subjects' family overview}

The interview process was always conducted at the subjects' family house. At the first meeting the researchers explained the purpose of the interviews and asked for the family's willingness to be interviewed as the subjects. Both parents of the terrorist were willing to be interviewed on the condition that they did not have their names published, no pictures taken and no publishing of their full address. One of their children (SL) refused to be interviewed. As a sign of agreement, researchers handed informed consent to both parents to sign.

At the first meeting of observation and interview, the mother (MI) was expressive when telling stories. MI smiled often when telling funny things but became sad and cried when she reached the time that they found out that one of their children was a terrorist. MI sometimes held the hand of the researchers, held back her tears, raised her voice and stroked her chest when saying something that upset her. While the father (AB) was more reclusive, often responded with the same answers and briefly. $\mathrm{AB}$ seemed to find difficulty in expressing his feelings and several times responded with high intonation.

MI, which was initially very expressive during the first meeting, was more relaxed and comfortable at the second meeting although sometimes still showed sadness and resentfulness when telling stories. AB looked more comfortable to share at the second meeting, he was able to express his feelings for example when he was upset, he sighed, and his intonation was lowered. In the third meeting, both $\mathrm{MI}$ and $\mathrm{AB}$ were more comfortable than ever before, and they even tried to joke. $\mathrm{AB}$ and $\mathrm{MI}$ told the story calmly, but researchers could sense the emotions they felt.

The subjects' family consist of five members, father (AB), mother (MI), and 3 children (SN, $\mathrm{SL}$, and $\mathrm{SH})$. Their three children were born in the city of $S$ and the remaining siblings are married and have their own family. $\mathrm{AB}$ and MI married in the 70s, but they did not have children immediately, as MI was very young at that time. After being married for seven years they had SN, a few years later their second child SL was born followed by $\mathrm{SH}$ a few years later.

The economic condition of the family was classified as low economic class. In meeting the needs of the family, AB and MI worked on various jobs starting from selling bakso (Indonesian meatball) and martabak, bicycle courier, laborer on building sites, Chinese dodol makers, dancing Kuda Lumping (traditional Javanese dance), raised goats. MI was also a female laborer in Saudi Arabia for eight years.

When $\mathrm{SN}$ began to mature, he became the backbone of the family. He worked in iron mills and machinery plants and was entrusted to handle damaged machines. His income from his work helped finance his younger sibling's education until high school. SN also bought goats for his father (AB) to be kept and grazed. SN was known as a good, diligent, and smart boy, he was even granted scholarships for school and pesantren (Islamic Boarding School).

The family was very shocked to find out that SN was the perpetrator of the Sarinah Bombing. They found out about this when watching a live broadcast from television explaining the criteria of the perpetrators and that SN had been shot dead. In the early days after the bombing, the family condition was not good because they had to accept that their son (AB and $\mathrm{MI}$ ) or brother (SL and $\mathrm{SH}$ ) was the perpetrator of terrorism and they had lost a family member. There was rejection from the community when the body was going to be 
buried in the city of $\mathrm{S}$, it made the family very angry and sad. MI did not interact with the neighborhoods very often for almost a year, the atmosphere in the family turned more tense because almost everyday journalists or people unknown to $\mathrm{AB}$ and $\mathrm{MI}$ came visiting their home. One year ago (2018) MI started to open up by selling cilung (local snacks) in a school in her village.

\section{Belief system}

For the subjects' family life had never been easy but learning a family member was a terrorist was shocking, sad, and very difficult nevertheless the circumstances had to be accepted. The family had a positive belief and view that everything that happened to the family is the destiny of God. The family's view that the difficulties they were experiencing were part of God's plan and that they must learn from the event was very important for resilience (Antonovsky in Walsh, 2006). The family interpreted that SN becoming a terrorist was destiny, although it was difficult this belief has helped the family in adjusting to the circumstances that occurred at that time.

"Ora nyangka, kaget. Tapi kudu nerima bagen priwe blesak gah. Kaya uwong di jokot nyawane. Larane duh campurcampur.

(I didn't believe it, I was shocked. But I had to accept it's bad. Human's life is lost. The pain is mixed)."

W2.P.MI.RS.July12,2019.28-29.

"Ya beli wis takdire mengkonon ya diterima bae. Ya tapine sulit mah sulit tapi dibalik maning wis takdire mengkonon, da abah mah ora weruh awal mengkonon kuh kepriwe.

(It's his destiny we need to accept. It is difficult but again it's destiny, I didn't know how it started)".

W3.L.AB.RS.July 15,2019.36-38.

"Ya kaget campur aduk pikiran karo sing dirasa kuh, tapi kudu biasa bae, wis kudu dilakonie mengkenen sing gusti Tuhan.
(Shocked, mixed thoughts and feelings but had to act normal, must live with this because it's God's fate)".

W1.L.AB.RS.July7,2019.62-63.

"Ya kuen weruh bocah melu mengkononan teroris, da bocah kuh meneng, rajin. Baka ana sing kurang ning sn sing bantu, bocah sing paling perhatian, nelponi bae emih, priwe kabare. Bocahe soleh sn kuh.

(Found out my son was a terrorist, he was quiet, diligent. He helped us financially, he was the most attentive child, called me all the time and asked me how I was, SN was a very good child)". W1.P.MI.RS.July5,2019.74-76.

"Lemes, kaget, nangis tapi ora metu banyu mata kah nok. Abah mikir kudu kuat, masa nangis kabeh.

(Mortified, shocked, crying but no tears. I think I have to be strong, we can't all cry)".

W1.L.AB.RS.July7,2019.84-83.

"Rasa kaget mah ana, kaya wong ilang pikirane. Ora bisa mikir apa-apa, ya dibalikna maning, wis kudune mengkonon. Wis takdire, ya ngerasa kaget.

(There was a shock there, like losing my mind. I couldn't think of anything, but again, it was supposed to happen. It's his destiny, but still feel shocked)".

W2.P.MI.RS.July12,2019.9-10.

"SN dadi teroris, Abah kuh ora nyangka bocah mengkonon meneng, ora akeh ngomong, nurut ning wong tua. Eh mengkonon.

(SN became a terrorist, I never suspected that, the boy was quiet, not much to say, very obedient. He changed like that)".

W1.L.AB.RS.July7,2019.57-58.

TA, a significant other saw the reaction of the family after the incident, and he did not believe that one of the members of the family could be a terrorist. 
"Expression of disbelief, crying. From what I saw they looked shocked, surprised, despite knowing or not knowing his behavior, there was sadness and shocked". W1.L.TA.KDK.RS.July13,2019.19-21.

Upon hearing the news, the family became frightened when they left the house. The parents were worried for the other children, worried of hearing bad words from others. Therefore, they closed their home. They did not want other family members to become terrorist following their brother's footsteps (the perpetrator).

"Ya sekeluarga, doa ngaji seanak putu ning kene, pada ngaji kabeh. Wong pada teka mang umah, ya ditutup kabeh umahe, wedi emih metu kuh blawehi adi-adine metu melang di tangkep maning, pokoke mah wedi metu sing umah kuh bokat ana omongan sing blesak. Dadi ning jero wirid, doa. Ambir tenang emihe sekeluarga.

(The whole family prayed including our children and grandchildren. All of us. People kept coming, but the doors remained shut, I was scared that if my children went outside, they would get caught, afraid of hearing people talking bad about us. So, we just stayed inside and praying hoping that my family felt more peaceful.)"

W3.P.MI.RS.July15,2019.68-71.

"Lebih parek ning gusti Tuhan, dadi nambah tenang. Maih weruh ning bocah ning adi-adine kon aja kaya kakange ira, blesak kelakuane cukup raup kakange ira bae. Di jokot sing baguse sing blesake aja di tiru.

(Closer to God, to feel peaceful. I told my children not to follow in his footsteps, let him alone be bad. Take good things from him but don't adopt his bad behavior)". W1.L.AB.RS.July7,2019.120-122.

"Ya ana, aja sampe mengkonon maninglah, urip sing adem, sedina-dina kecukupan

(Yes, I hope it doesn't happen again, have a peaceful life, fulfilled daily needs)".
W2.P.MI.RS.July12,2019.40.

"Ngingetna bocah aja bosen, nasehati aja sampe mengkonon. Tapi ora terlalu kaya bocah cilik, wis pada duwe keluarga dewek.

(Always reminded my children not to be bored, advised them not to follow their brother's path. But I didn't talk like they are small children, because they have their own families.)"

W2.P.MI.RS.July12,2019.42-43.

Similar findings from the research of Rufaedah and Putra (2018) that knowing a family member is a terrorist makes the other family members feel sad, traumatized, embarrassed and never want the same things to happen again. The families of a terrorist do not expect other family members to get involved in terrorism (terrorists).

According to Walsh (2003, in Jones et al., 2018) spirituality is one of the keys to family resilience. The subjects gave meaning to the event of terrorism act with their spirituality. Spirituality has a great influence on the family.

"Nyesuaikene ya abah nerima, terus paling kien wis takdire abah, takdire mengkonon. Abah ora weruh kan, kecolongan ibarate mah.

(I try to adjust and accept, this is my fate, it is what it is. I didn't know, I somehow missed it)"

W2.L.AB.RS.July10,2019.49-50.

The incident has made the family stronger spiritually and religion has remained the principle of their lives.

"Semakin parek nok, tapi seawit bengen gah abah mah wis panut ning gusti Tuhan. Pas ana masalah mengkonon masa garep adoh sing gusti Alllah, jaluk ning sapa maning lamon ora karo gusti Allah. Jaluk kuat jaluk sabar jaluk segala-galane. Segala blenak wis dirasani kabeh, ampe lagi dagangan pas abah lagi taat duit dagangan ana sing nyolong, disangka 
pesugihan, dibayar Cuma 1 liter beras sing awit esuk tekang tas bedug.

(I'm getting closer to God, but I have been faithful. When dealing with problems like this we can't be away from God, who would help us but God. Asking for strength and patience. I have experienced all the bad things. I was selling and while I stopped to pray, my money was stolen. I have been accused of using magic to finance my family, paid only 1 liter of rice working from early morning to noon)"

W1.L.AB.RS.July7,2019.31-36.

\section{Organizational patterns or family relationships}

The subjects' family relationships are not so close to each other. This was apparent after the family found out that one of the family members was a terrorist, the family who were still shocked then gathered to discuss how it could happen. It turned out that none of the members of the family knew and in fact, SL (the perpetrators sibling) claimed to rarely talk to $\mathrm{SN}$ (perpetrator).

"...langsung rembukan bareng, abah emih ngomong aja sampe ana mengkenen maning. Mih kuh duwe anak ora akeh, terus a ne sira kelakuane kayang konon wis aja di tiru. Abah ampe ngomong masa sira (ke SL) ora weruh kakange mengkonon.SL jawab ya niing emih abah bae ora ngomong apa maning ning kita, sing jarang ngobrol. Yawis sekien mah jokot sing bagus, sing blesak aja di jokot. (...we discussed it straight away, your father and mother will talk but not to press you. I don't have many children, don't follow your brother's bad behavior. My husband said how come you do not know your brother was dealing with something like that. SL said that if he didn't talk to you mom and dad, why would he talk to me, we rarely talk. Ok, now let's take good things from him but don't adopt his bad behaviors)".

W2.P.MI.RS.July12,2019.123-128.
There was a change in MI's daily routine after the incident, while $A B$ still went to the rice fields looking for grass for his goats. One of the factors affecting family resilience is duration or time (Walsh, 2003; Qiu et al., 2021). MI needed about a year to recover.

"Suwe ana setahun ora mendi-mendi emih mah, lamon inget maning, ya sakit maning, sampe mang nasuka ngiderna lawuhan dewek kuh. Akeh pikiran dadi blenak.

(I didn't go anywhere for a whole year; the pain came back when I remembered. Mang Nasuka even peddled his own food. A lot of thoughts so uncomfortable)". W2.P.MI.RS.July12,2019.78-79.

"Oh laka, abah kan ngarit. Wedus kudu mangan. Masa gara-gara kien wedus ora mangan, arane nyiksa. Ya abah mah tetep miyang ngarit bagen situasine lagi ora bener gah, duwe tanggung jawab. Paling lamon lagi laka sulit, lagi kesusahan laka duit, baru abah kuh inget. Priwe gah bocah kuh bener ning wong tua, nyukupi segala kebutuhane.

(Nothing, I went looking for grass. The goats had to eat, and I didn't want to torture them. I had to go out even though the situation was not right, I had responsibilities. When we didn't have problems, when we had financial problems, I remembered how good my son was to his parents, fulfiled all of our needs)"

W1.L.AB.RS.July7,2019.96-99.

"Masih pengajian mah, sedurung kejadian, setelah kejadian gah abah tetep miyang. Ora marian. Garep apa ning umah bae kuh, abah mah sedina-dina gah ora ning umah bae.

(Praying, before the incident, after the incident I still went out. I didn't stop. What would I do at home, I didn't stay at home all day)"

W1.L.AB.RS.July7,2019.101-102.

Providing support to the members of the family is done when going through difficult 
times. AB tends to provide more support to MI who sometimes still feels sad.

"Diingetna, ambir apa sih nangis kuh. Wis doa bae aja diinget-inget, jaluk ning gusti Tuhan ambir pada tenange, Wis nasibe keluarga abah.

(Remind her not to cry. Pray and try to forget, ask God to give us peace, it's our family's fate after all)"

W2.L.AB.RS.July 10,2019.63-64.

"Lebih keingetaken, wis aja dipikiri sing wis lewat wis sekien wayahe bangkit maning.

(Remind her more not to think about it, it has happened, and it is time to recover now)"

W2.L.AB.RS.July10,2019.56-57.

When SN was alive, he was an important figure in the family. His role was becoming the backbone of the family and sometimes as the family leader.

"Ya SN, bocah kuen mah nurut, mandiri, biayani keluarga kabeh. Sing nasehati keluarga kayang apa lamon pen usaha.

(Yes SN, he was obedient, independent and financed the whole family. He taught us how to sell)"

W1.L.AB.RS.July7,2019.47-48.

"Ya abah meneng bae, dadi mih sing sering bijaki, sing ngambil keputusan. Tapi pas ana SN, SN sering sering kudu mengkenen, sing bijaki.

(My husband remained quiet; I was the mediator who made decisions. But when SN was around, he gave opinions, he was the mediator)"

W2.P.MI.RS.July12,2019.148-150.

"SL sing bijaksanai mana mene, mih abah kudu kepriwe. Wong tua beli ngarti.

(SL was very wise, told us what we were supposed to do. We didn't understand)"

W1.L.AB.RS.July7,2019.89.

After the incident, the family felt excommunicated from the community and the struggled with financial difficulties since SN was the backbone of the family.

"Laka nok laka sing baturi, laka bantu duit tah apa, laka sing peduli. Laka sing takon paling bisa di itung sapa sing mene bae kuh.

(No one, no one beside us, no financial or any other help, no one cared. No one asked, I can count on my fingers who came to visit)"

W1.P.MI.RS.July5,2019.177-178.

"Biasane kah sing bantu gede-gedean kan sn, bantu secara ekonomi, ya kuen iku masih isok kelingan perhatiane. Bagen masih ana sing ngomong teroris lah priwe, yawis di eleg bae omongane, wis kepriwe maning.

(Normally the greatest help came from $\mathrm{SN}$, economically, I still remember his attention. Let people still say he's a terrorist, I'll just listen, what else can I do)"

W1.P.MI.RS.July5,2019.166-168.

To meet the daily needs, MI (mother) decided to sell food.

"Langsung, pertama ning sekolah. Alhamdulillah laris nok, prangsane mah uwong kuh dau deleng mih maning wis lawas kuh. Rame dagangan kuh entok. Uwong pada nakoni mendi bae jeh, ya mih jawab ana ning umah. Kadang mih gah masih jokot lawuhan ning mang nasuka, midere tas dzuhur. Alhamdulillah nok pada bae larise. Seneng emih kuh uwong pada tuku, bagen akeh sing dagang gah, tetep ana sing tuku..."

(First day selling at school, Thank God it's sold out. People might think I've been off too long, it was busy and sold out. People asked me where I have been, and I said I have been home. Sometimes I still took food from Mang Nasuka, to sell in the afternoon. Thank God the selling was also good. I was happy that people would buy from me, although many competitors out there, they still bought from me ...)" W2.P.MI.RS.July12,2019.89-93. 
"Abah mah langsung mah sawah, ngarit kan wedus kudu diempani. Abah mah ning umah bae ora suwe kaya mih, lamon mih kan suwe.

(My husband went to the rice fields, looking for grass for the goats. He didn't stay home for long, unlike me)"

W2.P.MI.RS.July12,2019.101-102.

Before and after the incident they continued to join in the big family recitation. According to $\mathrm{AB}$ meting his extended families made him happy.

“...lamon sekien melu pengajian keluarga besar sing di pimpin ning ustad enjang. (No, now joining with big family recitation led by Ustad Enjang)"

W3.P.MI.RS.July15,2019.2.

"Biasa bae, kaya sedurung-sedurunge, laka perubahan bagen tas masalah kuen gah. Tetep miyang menggawe, tetep melu pengajian mingguan, tetep melu pengajian ning yayasan.

(Normal, just like before, no changes even after the incident. Keep going to work, join weekly recitations, recitation at the foundation)"

W3.L.AB.RS.July15,2019.13-15.

Families who experience difficult situations over a long period of time require adjustment to the situation experienced (I). This is also encountered by the family of terrorists because they have to accept the reality (as a difficult situation) and need a long adjustment for family members to accept this. It took a year for MI to be absolutely sure that she was okay.

\section{Communication process}

The subjects' family only communicate when there is something important to discuss, if there is nothing important, they don't really talk to each other. The family heard about the incident from one of their other children and then they checked on the TV and saw what had happened.
"Iya langsung, balik sing pengajian. Durung ana sing maih weruh abah. Weruh sing keluarga dewek terus deleng tv deleng beritane. Ya arane wong tua ora weruh asal usule kenang apa mengkonon. Dadi ya kaget, lemes, lah anake kita mengkonon sih meluan teroris-teroris.

(Yes, straight away, back from recitation. None told me. I heard from my family and checked the news. As a parent who didn't know how come my son got involved with this, I was so shocked, mortified. Why did my son join with terrorists?)"

W2.L.AB.RS.July10,2019.12-15.

"Ngobrol lamon ana penting, lamon ora ya meneng bae. Ngobrol seanane baelah. (We talked only when we had important things to say, the rest we just stayed quiet, or just said whatever came to mind at the time)"

W2.L.AB.RS.July10,2019.78.

HM and TA as the significant others for the terrorist family claimed that the subjects' family considered a quiet family who didn't like to share about their problems. After the incident, the family became more reserved.

"Keluarga kuen mah termasuk keluarga meneng, ora akeh cerita. Bapak kerungu sing sedulur sejene.

(They are a quiet family. They do not share. I know about this from other relatives)".

W1.L.HM.RS.July13,2019.18-19.

"Biasa bae, tapi kaya lebih ketutup maning, bengen wis meneng kan termasuke. Ya sekien nambah meneng maning. Nambah adoh.

(Just like usual, but more closed now. They used to be quiet, but now more so. Feeling further away, distant)".

W1.L.HM.RS.July13,2019.21-22.

The parents tended to harbor their sadness and were diverted to positive things such as praying, recitation and dhikr or keeping it to themselves and not revealing everything. Meanwhile, a well-functioning family can 
comfortably express positive emotions such as happiness, gratitude, love and hope as well as negative emotions such as sadness, fear, anger, and disappointment (Walsh, 2006).

"Ora, laka sing cerita. Palingan mih dewek sing cerita masalah mih lamon lagi blenak pikiran blenak awak, tapi abah atau SL mah ora cerita...

(No. No one talked about their problems, I did sometimes when I felt troubled or unwell, but my husband or SL never ...)" W1.P.MI.RS.July5,2019.193-194.

"Ora, ora cerita sebenere, ya paling ngomong ora olih selangan sing kuen, ora dipaih. Olamon cerita kabeh ora tegel, sing ana malah tukaran karo dulur. Dadi di pendem bae.

(No. I didn't say in detail, I just said you can't borrow and then I didn't give it to them. I didn't have a heart to tell everything, we could get upset with each other. So, it is better I keep it to myself)". W2.P.MI.RS.July12,2019.60-62.

"Yaiya, masa meneng bae, lamon duwe kepengenan. Tapi lamon lagi ngenes mah ya meneng bae, abah ngaji, wirid. Lamon seneng ya ngungkapna tapi jarang

(Yes, if we want something we say it. But when we are upset, we stay quiet, I pray and dhikr. When we are happy, we say it but it's really rare)"

W2.L.AB.RS.July10,2019.81-82.

"Ya paling cerita masalah usaha kepriwe, kan sekien dagangan cilung, ya takon ana untunge belih. Ya emang manusia. Punya segala-gala cobaan. Pasti ana, tapi manusia ne pen kepriwe, abah sih jaluke di kuatna iman lan islam.

(Yes, she told me about her business, now she is selling cilung, I asked if she makes a profit. Human's life always faces trials. Always, but it is our choices, I always ask for strong faith in Islam)".

W2.L.AB.RS.July10,2019.84-86.

When they found out that one of the members of their family was involved in terrorism, the rest of the family was shocked, in disbelief and sad. In the aspect of belief system of family resilience, the subjects could interpret all the events well by associating them with spirituality. The family accepted the fact that their son was a terrorist and they believed this was God's destiny, although the process of acceptance was not quick and easy. The parents were afraid to leave the house because they were worried the other members of the family would be arrested, they were also afraid of hearing people talking bad about their family. As parents, $\mathrm{AB}$ and MI often advised their children not to follow in their brother's footsteps to become terrorists. This event has drawn the family closer to God. According to Walsh (2006) a belief system is when a family faces difficulties and give meaning by associating it to the social environment, cultural values, spirituality and previous generations with the hope of the future. The subjects' family gave the meaning to the incident with their spirituality. This is in line with what Walsh (2016) has stated that belief is at the core of who we are and how we understand our experiences.

In the process of organizational patterns or family relationships, family members are not so close to each other. When finally finding out that one of the members of their family was a terrorist, no one knew SN's recent activities. Distant relationships and lack of communication affects the family's ability to adapt. After the family experiences a stressful event, there will be an adjustment of the new family function pattern. One of the successes of family adaptation is determined by interfamily interaction (Ahlert \& Greeff, 2012).

Adaptability of subjects varies. MI (mother) needed about a year to be able to resume activities as usual. Previously, MI preferred to cover up by being at home for fear of hearing people talking about their son. While AB (father), remained active as usual (looking for grass for goats and joining recitation) right after the incident happened. In the family, SN (child as well as terrorist) had the role of the backbone of the family and sometimes as a 
leader. $\mathrm{AB}$ and $\mathrm{MI}$ often remember how kind $\mathrm{SN}$ was to the family, $\mathrm{AB}$ provides support to MI when she is going through difficult times. After SN had gone, MI returned to selling food to finance the family. In the communication process, the subjects' family are known to be a closed family according to significant others. Based on the interview, they also revealed that they don't frequently communicate, and are not very good at expressing what they feel and speak only when necessary. The feelings they have tend to be buried within and diverted by recitation, prayer, dhikr. If they must reveal or talk about something, they will not reveal much. The bombing incident also keeps the family closed from the surrounding neighborhood. Meanwhile, a well-functioning family can comfortably express positive emotions such as happiness, gratitude, love and hope as well as negative emotions such as sadness, fear, anger, and disappointment (Walsh, 2006).

\section{CONCLUSION}

The conclusion from this research is that the family of the terrorists have gone through the process of becoming resilience and they have utilized the powers and resources that exist to improve the family resilience. The findings also show that each family has its own strength and ways to deal with difficult conditions, especially in this research, family resilience was forged by finding out that a family member was involved in an act of terrorism. Advice for the family is not to feel discouraged when faced with such an incident, no need to close themselves from the environment, do not hesitate to ask for support, help from extended family and the community, and express one another's feelings or thought openly.

\section{REFERENCES}

Ahlert, I. A., \& Greeff, A. P. (2012). Resilience factors associated with adaptation in families with deaf and hard of hearing children. American Annals of the Deaf, 157(4), 391-404. doi:10.1353/aad.2012.1629
Ahmad, M. M. S., \& Ula, M. (2012, 5-8 November). Perempuan dibalik teroris: Kajian religiusitas, penyesuaian diri dan pola relasi suami isteri tersangka teroris di Kota Pekalongan. Conference Proceedings: Annual International Conference on Islamic Studies (AICIS) XII. Jakarta. http://digilib.uinsby.ac.id/id/eprint/7568

Asiyah, S. N., Fauziyah, N., Khotimah, S. K., \& Balgies, S. (2014). The social discrimination against former terrorist convicts and their families: psychological perspectives. Journal of Indonesian Islam, $8(1)$

71-90. http://dx.doi.org/10.15642/JIIS.2014.8.1. 71-90

Badriyanto. (2018, 15 May). 3 kesamaan aksi teror bom di gereja dengan Mapolrestabes Surabaya.

Okezone. https://news.okezone.com/read/2018/05/1 5/519/1898395/3-kesamaan-aksi-terorbom-di-gereja-dengan-mapolrestabessurabaya

Guru, S. (2012). Under siege: Families of counter-terorism. British Journal of Social Work, 42, 1151-1173. Doi: 10.1093/bjsw/bcs089

Ilias, K., Cornish, K., Park, M. S., Toran, H., \& Golden, K. J. (2019). Risk and resilience among mothers and fathers of primary school age children with ASD in Malaysia: A qualitative constructive grounded theory approach. Frontiers in Psychology, 2275. https://doi.org/10.3389/fpsyg.2018.02275

Jayanti, D. A., \& Indrawati, E. S. (2015). Subjective experience to be wife of convicted terrorism. Jurnal Empati, 2(4), 115-126.

https://ejournal3.undip.ac.id/index.php/e mpati/article/view/7397

Jones, K. F. Dorsett, P., Simpson, G., \& Briggs, L. (2018). Moving forward on the journey: Spirituality and family resilience 
after spinal cord injury. Rehabilitation Psychology, 63(4), 521. https://doi.org/10.1037/rep0000229

Maghfur, M., \& Muniroh, S. M. (2013). Women behind terrorists (religiousity, self adaptation and husband-wife relationship within suspected terrorists family in Pekalongan). Analisa: Journal of Social Science and Religion, 20(2), 181-195.

Mustofa, I. (2012). Terorisme: Antara aksi dan reaksi (gerakan Islam radikal sebagai respon terhadap imperialism modern). Jurnal Religia, 15(1), 65-87. https://doi.org/10.28918/religia.v15il.123

Nurfitri, L. E. (2018). Komunikasi sosial keluarga besar mantan teroris di Desa Tenggulun Kecamatan Solokuro Kabupaten Lamongan [Undergraduate thesis]. UIN Sunan Ampel Surabaya. http://digilib.uinsby.ac.id/26590/.

Poerwandari, E. K. (2013). Pendekatan kualitatif untuk penelitian perilaku manusia. LPSP3UI.

Qiu, Y., Xu, L., Pan, Y., He, C., Huang, Y., Xu, H., Lu, Z., \& Dong, C. (2021). Family resilience, parenting styles and psychosocial adjustment of children with chronic illness: A cross-sectional study. Frontiers in Psychiatry, 12, 646421. https://doi.org/10.3389/fpsyt.2021.64642 1

Rahmah, A. F., \& Widuri, E. L. (2011). Post traumatic growth pada penderita kanker payudara. Humanitas: Jurnal Psikologi Indonesia, $\quad 8(2)$,

115-128.

Rahmawati, A. R., Hakim, S. N., \& Chusniatun, M. A. (2018). Ketangguhan istri pelaku radikal dalam menjalani hidup ditinjau dari religiusitas [Undergraduate thesis]. Universitas Muhammadiyah Surakarta. http://eprints.ums.ac.id/69336.

Rufaedah, A., \& Putra, I. E. (2018). Coping with stigma and social exclusion of terrorconvicts' wives in Indonesia: An interpretative phenomenological analysis. The Qualitative Report, 23(6), 1334-1346. https://nsuworks.nova.edu/tqr/ vol23/iss6/5

Sujoko, S., \& Mukti, P. (2018). Gambaran striving for superiority pada keluarga teroris. Intuisi: Jurnal Psikologi Ilmiah, 10(3), 248-256. doi: 10.15294/intuisi.v10i3.18865

Ulfiyatun, A. (2015). Makna menjadi keluarga 'teroris' bagi keluarga tersangka terorisme Amrozi dan Ali Ghufron di Desa Tenggulun, Kecamatan Solokuro, Kabupaten Lamongan. Masyarakat, Kebudayaan dan Politik, 28(2), 70-79. http://dx.doi.org/10.20473/mkp.V28I220 15.70-79.

Waheed, A., \& Ahmad, M. M. (2012). Socioeconomic impacts of terrorism on affected families in Lahore, Pakistan. Journal of Aggression, Maltreatment \& Trauma, 21(2), 202-222.

Walsh, F. (2003). Family resilience: A framework for clinical practice. Journal of Family Process, 42(1), 1-18. http://dx.doi.org/10.1111/j.17413729.2002.00130.x

Walsh, F. (2006). Strengthening family resilience (2nd ed.). The Guildford Press.

Walsh, F. (2016). Strengthening family resilience (3rd ed.). The Guilford Press. 